\title{
Liquid Chromatography Tandem Mass Spectrometry Method for Ultra-Trace Analysis of Organic UV Filters in Environmental Water Samples
}

\author{
FLORENTINA LAURA CHIRIAC*, IULIANA PAUN, FLORINELA PIRVU, LUOANA FLORENTINA PASCU, \\ MARCELA NICULESCU, TOMA GALAON \\ National Research and Development institute for Industrial Ecology, 71-73 Drumul Podu Dambovitei Str., 060652, \\ Bucharest, Romania
}

\begin{abstract}
A liquid chromatography-tandem mass spectrometry (SPE-LC-MS/MS) method was developed and validated for the simultaneous determination of six organic compounds (2-hydroxy benzophenone, 4hydroxy benzophenone, 2,2',4,4'-tetrahydroxy benzophenone, 2,4-dyhydroxy benzophenone, 4,4'dyhydroxy benzophenone, 2,2'-dyhydroxy-4-methoxy-benzophenone) used as UV filters in personal care products used to protect against UV radiation. The major concern about this type of pollutants is due to their persistence and bioaccumulation potential in the environment and aquatic organisms and for their endocrine disruptor properties. Solid phase extraction was used for sample preparation, followed by liquid chromatography tandem mass spectrometry analysis. Benzophenone derivatives were analyzed on a Phenomenex Luna C18 column (150 x $2.0 \mathrm{~mm}, 3.0 \mu \mathrm{m})$ with the mobile phase run in gradient mode with a mixture of aqueous $0.1 \%$ formic acid and acetonitrile as the mobile phase components (at a flow rate of $0.2 \mathrm{~mL} / \mathrm{min}$ ). MS detector response was linear, on the tested concentration domain from 1 to $100 \mu \mathrm{g} / \mathrm{L}$ with correlation coefficient $R^{2}>0.998$. The recoveries of benzophenone derivatives after solid phase extraction procedure from surface water was found to be $>81 \%$ for surface water and higher than $79 \%$ for wastewater matrix. The standard deviation values for intra-day precision were situated between $7.67 \%$ and $9.88 \%$ for lower concentration and $7.27 \%$ and $8.86 \%$ for higher concentration respectively. The limits of quantitation were calculated for both environmental water matrices (1.6-4.1 $\mathrm{ng} / \mathrm{L}$ for surface water and 3.3-8.2 $\mathrm{ng} / \mathrm{L}$ for wastewater). This method can be applied for benzophenone derivatives detection in real environmental samples.
\end{abstract}

Keywords: organic UV filters, benzophenone derivatives, solid phase extraction, LC-MS/MS, method

In the last years, the concern for sunburn, premature aging of the skin and the risk of developing skin cancer has increased with awareness of the negative effects of UV radiation to human health. Although UV filters are mainly incorporated in cosmetics (sunscreens, skin care, facial make-up and lip care products), they are also included in a wide range of products including plastics, adhesives, paints and rubber to protect against UV degradation. Organic chemicals used to protect against ultraviolet radiation absorb UV light (while inorganic compounds reflect UV light) and generally can be divided as UV filters used in personal care products (PCPs) to protect skin and hair sunburns and as stabilizers used in the manufacture of technological products such as plastics and paints to protect pigments and polymers against discoloration or photodegradation. PCPs with high sun protection factor (SPF) are the most popular among consumers, yet the "fake" feeling of protection leads to prolonged exposure to the sun. To increase SPF values, multiple combinations of UV filters are used, and their total concentration in the final products is much higher. This results in an increased exposure of the population to a larger and more diverse concentration of UV filters [1]. It is well-known that UV filters used in the production of PCPs can enter the aquatic environment directly from water sports activities and indirectly through effluent discharges [2-5]. The presence of UV filters in the environment may be seasonal, with higher concentrations being detected in wastewater more in summer than in winter. This is also true for the emissaries which show the same distribution pattern with higher concentrations in the summer than in autumn.

*email: laura.badea88@yahoo.ro 
UV filters have been detected both in environmental matrices (water, soil and sediments) as well as human body fluids such as blood and urine [5-7]. In vitro and in vivo studies have demonstrated that some UV filters have estrogenic effects $[8,9]$. In the US, 2-hydroxy-4-methoxybenzophenone is widely used in the production of personal care products with solar protection factor $(2 \mathrm{OH}-4 \mathrm{MeO}-\mathrm{BP})$ [10]. When sunscreen creams containing $2 \mathrm{OH}-4 \mathrm{MeO}-\mathrm{BP}$ are applied to the skin, $1-2 \%$ of the applied amount reaches the blood in about 10 hours [11]. Furthermore, 2OH-4MeO-BP has been shown to adsorbed in human skin more easily than other sunscreen products. $2 \mathrm{OH}-4 \mathrm{MeO}-\mathrm{BP}$ has been shown to have estrogen-like activity, being thus considered an endocrine disruptive potential [12]. Other studies in animals have shown that 2-OH-4$\mathrm{MeO}-\mathrm{BP}$ is metabolized in 2,4-dihydroxybenzophenone (2,4-OH-BP) and 2,2'-dihydroxy-4-methoxybenzophenone 2'$\mathrm{OH}-4 \mathrm{MeO}-\mathrm{BP})$, these benzophenone derivatives being themselves used as UV filters in sunscreen creams [13]. It is interesting to note that 2,4-OH-BP have an estrogenic activity higher than 2-OH-4-MeO-BP. In addition, other benzophenone derivatives such as 4-hydroxybenzophenone (4-OH-BP) and 2,2 ', 4,4'-tetrahydroxybenzophenone (2,2', 4,4'-OH-BP)have higher estrogenic activity than that of 2-OH-4MeO-BP [14]. Despite their potential to affect endocrine system activity, information on the existence of benzophenone derivatives, with the exception of 2-OH-4-MeO-BP, in humans is very rare.

During the last two decades LC-MS/MS has been extensively used in the environmental research for detection and quantitation of various classes of organic non-volatile pollutants from polar compounds like nitrosamines, pharmaceuticals and personal care products, to more non-polar ones: hormones, industrial compounds, halogenated flame retardants [15-20]. This versatility of LC-MS/MS is given by the large number of available stationary phases (with different polarity) able to separate polar and hydrophobic compounds and also to different types of ionization sources readily available in tandem MS instruments (ESI, APCI, APPI, Multimode Ionization) which enables determination of virtually all non-volatile analytes.

In this paper, we propose a new LC-MS/MS method for ultra-trace analysis of six organic compound used as UV filters in personal care products from environmental water samples.

Table 1

STRUCTURE AND SOME PHYSICAL-CHEMICAL PROPERTIES OF BENZOPHENONE DERIVATIVES

\begin{tabular}{|c|c|c|c|c|c|c|}
\hline No. & Compound & Abbreviation & Formula & $\begin{array}{c}\text { Molecular } \\
\text { weight }\end{array}$ & $\begin{array}{l}\text { Log } \\
\text { Kow }\end{array}$ & Chemical structure \\
\hline 1 & $\begin{array}{c}\text { 2-hydroxy } \\
\text { benzophenone }\end{array}$ & 2-OH-BP & $\mathrm{C}_{13} \mathrm{H}_{10} \mathrm{O}_{2}$ & 198.2 & 3.52 & \\
\hline 2 & $\begin{array}{c}\text { 4-hydroxy } \\
\text { benzophenone }\end{array}$ & 4-OH-BP & $\mathrm{C}_{13} \mathrm{H}_{10} \mathrm{O}_{2}$ & 198.2 & 3.07 & \\
\hline 3 & $\begin{array}{c}2,2^{\prime}, 4,4^{\prime}- \\
\text { tetrahydroxy } \\
\text { benzophenone }\end{array}$ & $\begin{array}{c}2,2^{\prime}, 4,4^{\prime}-\mathrm{OH}- \\
\text { BP }\end{array}$ & $\mathrm{C}_{13} \mathrm{H}_{10} \mathrm{O}_{5}$ & 246.2 & 3.16 & \\
\hline 4 & $\begin{array}{l}\text { 2,4-dihydroxy } \\
\text { benzophenone }\end{array}$ & 2,4-OH-BP & $\mathrm{C}_{13} \mathrm{H}_{10} \mathrm{O}_{3}$ & 214.2 & 2.96 & \\
\hline 5 & $\begin{array}{l}4,4^{\prime} \text {-dihydroxy } \\
\text { benzophenone }\end{array}$ & 4,4'-OH-BP & $\mathrm{C}_{13} \mathrm{H}_{10} \mathrm{O}_{3}$ & 214.2 & 2.19 & \\
\hline 6 & $\begin{array}{c}\text { 2,2'-dihydroxy-4- } \\
\text { methoxy- } \\
\text { benzophenone }\end{array}$ & $\begin{array}{l}\text { 2,2'-OH-4- } \\
\text { MeO-OH }\end{array}$ & $\mathrm{C}_{14} \mathrm{H}_{12} \mathrm{O}_{4}$ & 244.2 & 4.31 & \\
\hline
\end{tabular}




\section{Experimental part}

Materials and methods

Benzophenone standards

Individual high purity standards of 2-hydroxy benzophenone (2-OH-BP), 4-hydroxy benzophenone (4-OH-BP), 2,2',4,4'-tetrahydroxy benzophenone (2,2',4,4'-OH-BP), 2,4-dyhydroxy benzophenone (2,4-OH-BP), 4,4'-dyhydroxy benzophenone (4,4'-OH-BP), 2,2'-dyhydroxy-4-methoxy-benzophenone (2,2'-OH-4-MeO-OH) were purchased from Sigma-Aldrich.

\section{Reagents and chemicals.}

Methanol (MeOH) and acetonitrile (ACN) of HPLC-grade purity (Merck quality) and Acetic Acid (AA) and Formic Acid (FA) from Sigma-Aldrich.

\section{Preparation of standard solution stock}

A weight of exactly $0.025 \mathrm{~g}$ of 2-OH-BP, 4-OH-BP, 2,2',4,4'-OH-BP, 2,4-OH-BP, 4,4'- 4,4'-OH-BP, 2,2'-OH-4$\mathrm{MeO}-\mathrm{OH}$ was transferred into a $50 \mathrm{ml}$ volumetric flask and the volume was completed by ultrapure water and then ultrasonicated. $1 \mathrm{ml}$ of this solution was transferred into a $10 \mathrm{ml}$ flask and was completed to volume by using the same diluent. From this solution, $5 \mathrm{ml}$ was pipetted into a $10 \mathrm{ml}$ flask and was completed to volume by addition of the same diluent as above to obtain a solution of a concentration of $1 \mathrm{ppm}$.

LC-MS instrumentation and conditions. Experiments were performed using an Agilent

1260 series LC system (Waldbronn, Germany) coupled with an Agilent 6410B triple-quadrupole mass spectrometer with electrospray ionization source (ESI). Chromatographic separation was achieved using a Luna C18 (2) column (150 x $2.0 \mathrm{~mm}, 3.0 \mu \mathrm{m})$ from Phenomenex. The column temperature was set at $30^{\circ} \mathrm{C}$. A gradient elution was applied at a flowrate of $0.2 \mathrm{~mL} / \mathrm{min}$ (Table 2), using a mobile phase consisting of Aq 0.1\% FA and ACN. Injection volume of $20 \mu \mathrm{L}$ was used with Aq 0.1\% FA / ACN = 60/40 (v/v) as sample diluent.

Table 2

GRADIENT ELUTION PROGRAM USED TO SEPARATE THE SIX TARGETED BENZOPHENONES

\begin{tabular}{|c|c|c|c|}
\hline Time (min) & ACN (\%) & Flow-rate (mL/min) & Gradient line purpose \\
\hline 0.00 & 55 & 0.200 & \\
\hline 2.70 & 95 & 0.200 & analytical separation \\
\hline 7.00 & 95 & 0.200 & \\
\hline 7.10 & 55 & 0.200 & column re-equilibration \\
\hline 16.00 & 55 & 0.200 & \\
\hline 16.01 & 55 & 0.200 & \\
\hline
\end{tabular}

MS detection was achieved using MRM (Multiple Reaction Monitoring) acquisition mode. Retention time, fragmentor voltages, collision energies, MRM transitions and other MS parameters are given in Table 3. The mass spectrometer was operated in the negative electrospray ionization (ESI-) mode with drying gas temperature kept at $300^{\circ} \mathrm{C}, 8 \mathrm{~L} / \mathrm{min}$ drying gas flow, $4000 \mathrm{~V}$ capillary voltage and 30 psi nebulizer pressure.

Table 3

MS PARAMETERS FOR THE DETECTION OF BENZOPHENONE DERIVATIVES (MRM TRANSITIONS, COLLISION ENERGY)

\begin{tabular}{|c|c|c|c|c|c|c|c|}
\hline Compound & $\begin{array}{l}\text { Retention } \\
\text { time (min) }\end{array}$ & $\begin{array}{c}\text { MRM } \\
\text { transitions }\end{array}$ & $\begin{array}{l}\text { Fragmentor } \\
\text { voltage }(\mathrm{V})\end{array}$ & $\begin{array}{c}\text { Collision } \\
\text { energy } \\
(\mathrm{V})\end{array}$ & $\begin{array}{c}\text { Cell } \\
\text { Accelerator } \\
\text { Voltage (V) }\end{array}$ & $\begin{array}{c}\text { Capillary } \\
\text { voltage } \\
(\mathrm{V})\end{array}$ & $\begin{array}{c}\text { Dwell } \\
\text { time } \\
(\mathrm{msec}) \\
\end{array}$ \\
\hline $2,2^{\prime}, 4,4^{\prime}-\mathrm{OH}-\mathrm{BP}$ & 2.66 & $245 \rightarrow 91.0$ & 120 & 25 & 1 & \multirow{4}{*}{4000} & 250 \\
\hline 2-OH-BP/4-OH-BP & 3.79 & $197 \rightarrow 92.0$ & 150 & 35 & 1 & & 250 \\
\hline $\begin{array}{c}2,4-\mathrm{OH}-\mathrm{BP} / 4,4^{\prime}-\mathrm{OH}- \\
\mathrm{BP}\end{array}$ & 4.79 & $213 \rightarrow 135$ & 145 & 15 & 1 & & 250 \\
\hline 2,2'-OH-4-MeO-BP & 6.11 & $243 \rightarrow 93.0$ & 100 & 25 & 1 & & 250 \\
\hline
\end{tabular}




\section{Results and discussions}

\section{LC separation optimization}

Separation of the six organic pollutants was performed on a hydrophobic C18 type column. The optimization of the chromatographic liquid separation consists in the modification of the mobile phase with various organic solvents, acetonitrile and methanol, as well as the organic modifier using acetic acid and formic acid in various ratios Aq 0.1\% FA: $\mathrm{MeOH}$, Aq 0.2\% FA: $\mathrm{MeOH}$ and Aq 0.04\% AA: $\mathrm{MeOH}$, at a ratio of 30:70 v/v and Aq 0.1\% FA: ACN 30/70, 40/60, $45 / 55 \mathrm{v} / \mathrm{v}$. The highest analytical signal was obtained using the $0.1 \%$ aqueous phase modifier with both organic solvents (methanol and acetonitrile). Moreover, both isocratic and gradient mode were used for their chromatographic separation attempt. The attempt to separate the two pairs of isomers 2-OH-BP/4-OH-BP and 2,4-OH-BP/4,4'-OH-BP has led to the gradient use of the two tested mobile phases: Aq 0.1\% FA : MeOH and Aq 0.1 FA\%: ACN: 15-90\% ACN in 7 min, $55-$ $100 \% \mathrm{ACN}$ in $3 \mathrm{~min}, 55-95 \% \mathrm{ACN}$ in $2.7 \mathrm{~min}, 15-90 \% \mathrm{MeOH}$ in $7 \mathrm{~min}, 100 \% \mathrm{MeOH}$ in 3 minutes. Although none of the gradients used allowed the separation of the two isomers pairs despite their different hydrophobicity. Although, the binary Aq $0.1 \%$ FA : ACN mixture in the 55-95\% gradient in 2.7 minutes (Table 2) was chosen due to the narrow shape and width which were generated for all compounds, the two pairs of isomers being quantified as a sum. The small flow rate of only $0.2 \mathrm{~mL} / \mathrm{min}$ favored the ionization of the analytes in the electrospray source. After determining the content and optimum ratio of the mobile phase, another parameter that was varied was the column temperature, between $20-30^{\circ} \mathrm{C}(20$, 25 and $30^{\circ} \mathrm{C}$ ). Following these studies, it has been shown that although a low column temperature favors a better separation of analytes, the temperature of $30^{\circ} \mathrm{C}$ favors a much better and narrower form of the six UV filters. After setting the time segments, the Dwell time parameter was set to two values of 200 and 250 respectively, the latter generating a lower noise and, implicitly, a higher signal/noise ratio. The injection volume was also varied, the mixture of 6 pollutants being tested with 5,10 and $20 \mu \mathrm{L}$, respectively, the latter being chosen for higher method sensitivity at the trace level concentrations expected in surface water and wastewater. Optimized chromatographic parameters allowed separation of the 6 analytes in less than 16 minutes.

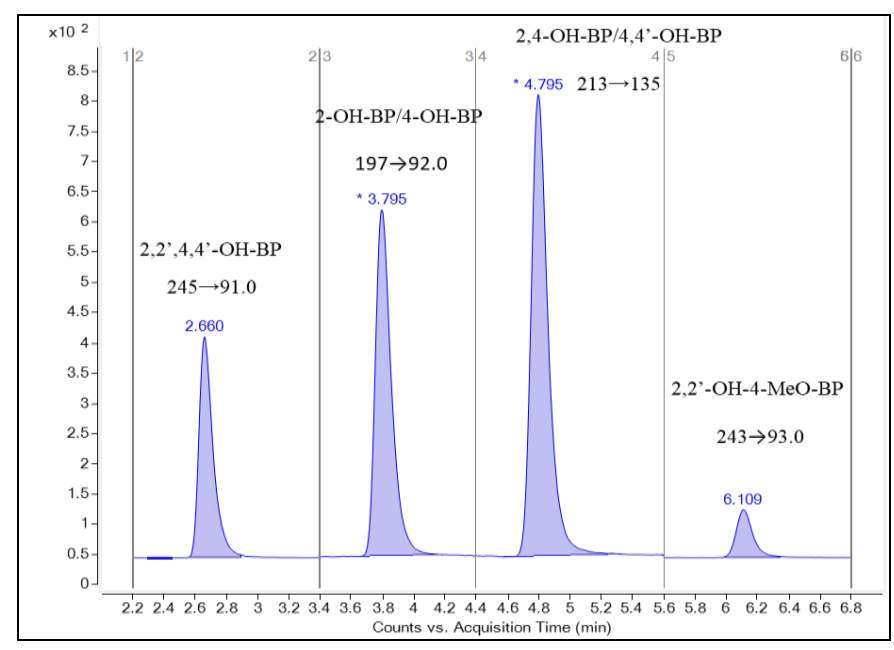

Fig. 1 Segments of acquisition used to optimize the separation of the six analysts

\section{MS detection optimization.}

During the development of the method for analytes detection in environmental water samples, it was attempted to obtain some lower detection and quantitation limits which allow the determination of extremely low levels (under ng/L) at which these compounds are expected to be present in the surface water samples. Thus, all the detection parameters of the triple quadrupole MS detector (QQQ) have been optimized. The optimized MS parameters: fragmentation voltage, collision energy (CE), collision cell acceleration voltage, quadrupole resolution (MS1, MS2 Res), dwell time, and capillary voltage. To optimize these parameters a $5 \mathrm{mg} / \mathrm{L}$ analytical solution mixture was used. With the modification of the mass spectrometric detection parameters their effect on the peak area and the signal/noise ratio $(\mathrm{S} / \mathrm{N})$ was monitored. As a result of these experiments, the mass spectrometric parameters which generated the highest sensitivity (peak area and signal-to-noise ratio) for the studied compounds were chosen. The values of the fragmentor voltage and the collision energy applied in the collision cell for molecular ion fragmentation varied between 90-150 V and 10-40 V respectively, the chosen values being those that generated the best area of the six compounds (Fig. 2). 


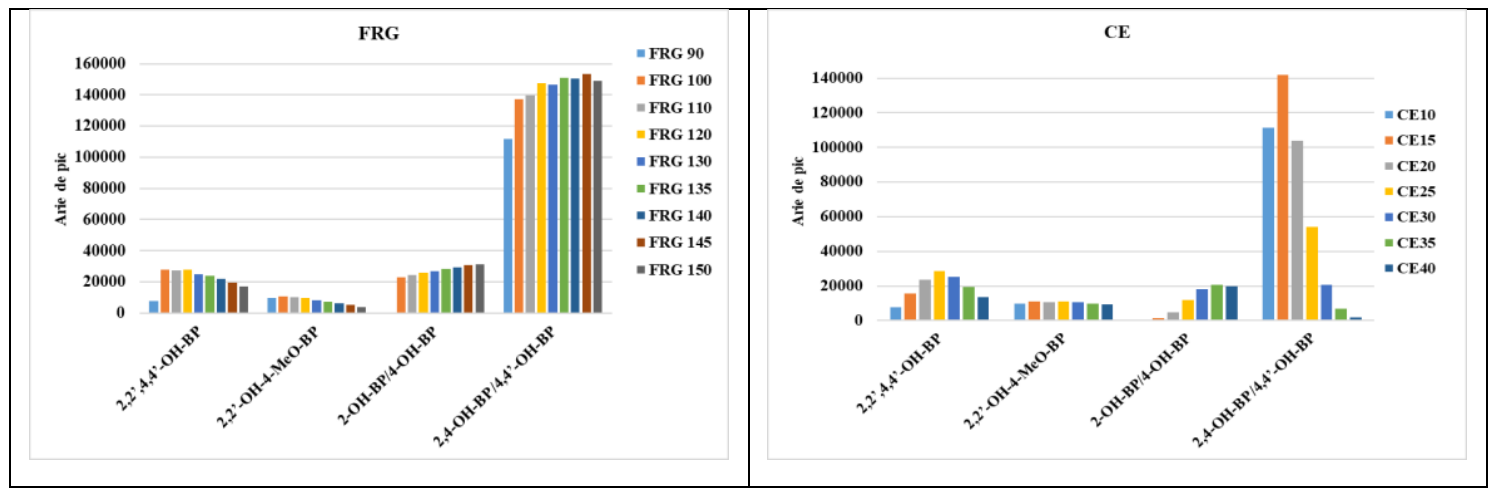

Fig. 2 Peak area variation with fragmentor voltage and collision energy respectively during MS method optimization for 6 benzophenone derivatives

Based on previous results, sensitivity optimization was continued with other MS detector parameters, namely capillary voltage, cell accelerator voltage, nebulizer pressure and drying gas flow-rate. The capillary voltage was varied between 3500 and $6000 \mathrm{~V}$, cell accelerator voltage between 1 and 8V (Figure 3), nebulizer pressure between 30-50 psi and drying gas flow-rate between 7-10L/min (Figure 4).

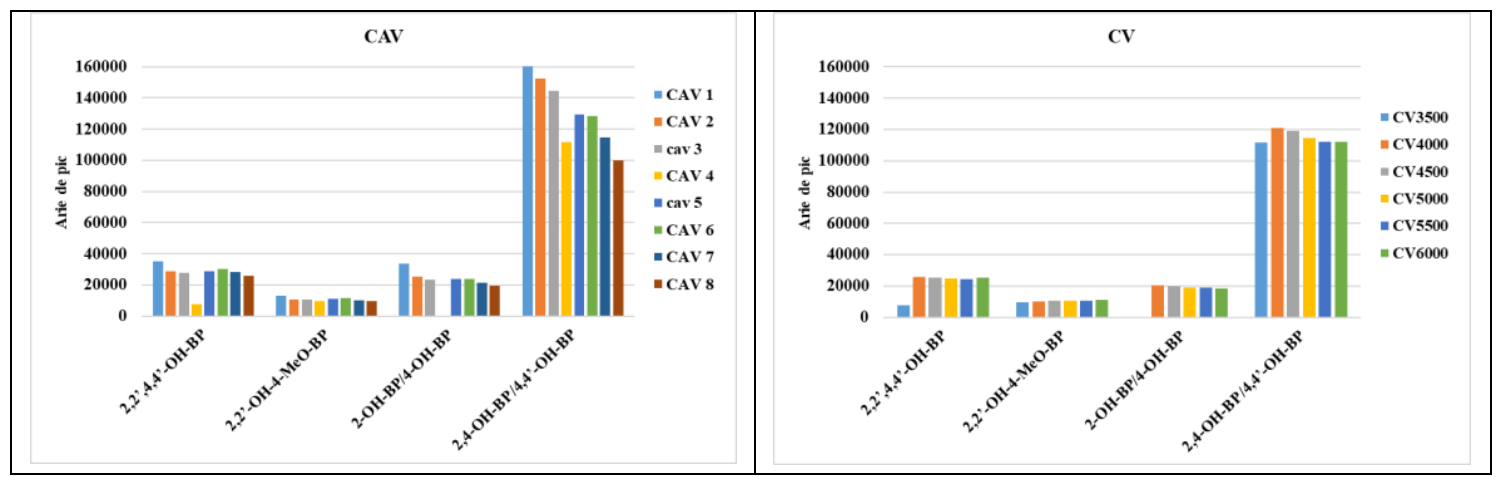

Fig. 3. Peak area variation with capillary voltage and cell accelerator voltage respectively during MS method optimization for 6 benzophenone derivatives

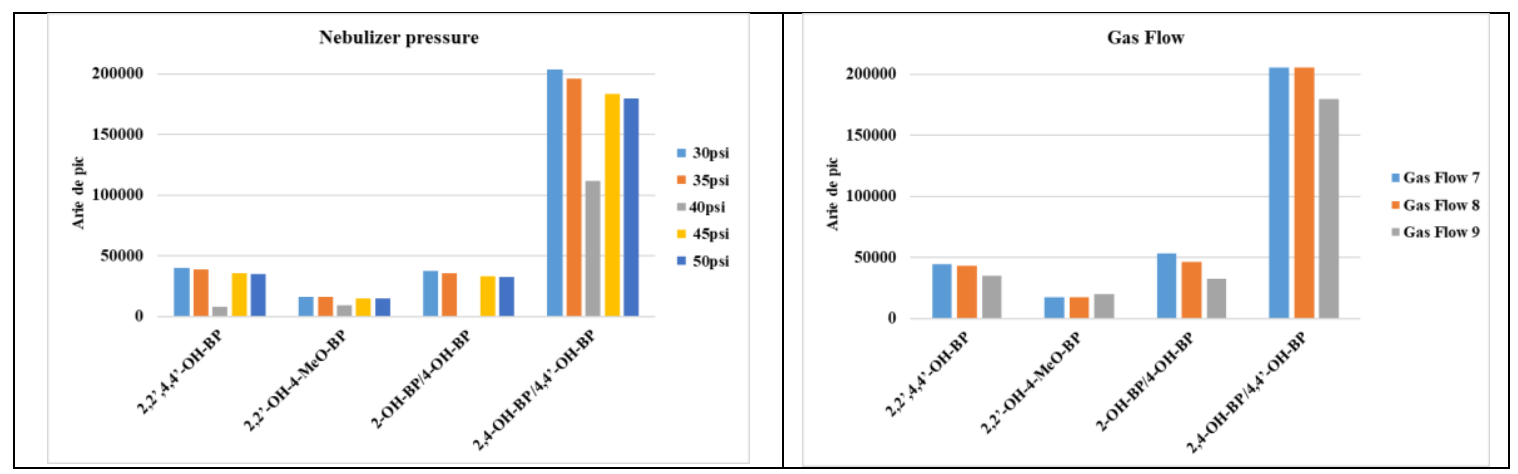

Fig. 4. Peak area variation with nebulizer pressure and gas flow respectively during MS method optimization for 6 benzophenone derivatives

The final chosen values, giving maximum peak area response, were: $300^{\circ} \mathrm{C}$ drying gas temperature, $4000 \mathrm{~V}$ capillary voltage, 30 psi nebulizer pressure and $8 \mathrm{~L} / \mathrm{min}$ drying gas flow. After optimization of mass spectrometric parameters, the IQL (instrumental quantitation limits) were determined to be between 0.46 and $0.71 \mathrm{ng} / \mathrm{mL}$.

\section{Sample extraction.}

The optimization of the LC-MS/MS analysis method was followed by the establishment of automatic solid phase extraction parameters (SPE) to allow the determination of the six benzophenone derivatives studied from surface water and wastewater samples at the ultra-trace level (ng/L). 
For the extraction of the analytes, the solid phase extraction procedure was used (SPE). Experiments on recovery of analytes from water samples by SPE extraction were performed using a Solid Phase Extraction System, SPE AutoTrace 280 Thermo Scientific Dionex. The recovery yield of the six organic UV-filters was evaluated using two types of cartridges: $30 \mu \mathrm{m}$ Strata X Cartridges with Polymeric Reverse Phase and C18 Hydrophobic stationary phase. The cartridges were conditioned with $10 \mathrm{~mL}$ of methanol and $10 \mathrm{~mL}$ of ultra-pure water. The water samples taken at work were $200 \mathrm{~mL}$ of surface water and $100 \mathrm{~mL}$ of waste water. After the entire water sample was passed through the cartridge (at a flow rate of $5 \mathrm{~mL} / \mathrm{min}$ ), the cartridge was washed with $10 \mathrm{~mL}$ of ultrapure water (at a flow rate of $20 \mathrm{~mL} / \mathrm{min}$ ). The adsorbent phase was dried under a gentle nitrogen stream for 30 minutes, the analytes being then eluted with $2 \times 4 \mathrm{~mL}$ of methanol at a reduced flow rate of $5 \mathrm{~mL} / \mathrm{min}$. The extracts were evaporated under a weak nitrogen stream and redissolved in a volume of $1.0 \mathrm{~mL}$ with a 60/40 (v/v) Aq 0.1\% FA / ACN binary mixture. Subsequently, the sample was transferred to an autosampler vial prior to LC-MS/MS analysis. The recovery yields were found to be higher for the extraction procedure in which C18 cartridges were used (Table 4).

Table 4

RECOVERY YIELD USING STRATA X AND STRATA C18 CARTRIDGES

\begin{tabular}{|c|c|c|}
\hline \multirow{2}{*}{ Analytes } & \multicolumn{2}{|c|}{ Recovery \% } \\
\cline { 2 - 3 } & Strata C18 & Strata X \\
\hline $2,2^{\prime}, 4,4^{\prime}-$-qOH-BP & 96.39 & 78.76 \\
\hline 2-OH-BP / 4-OH-BP & 86.48 & 82.61 \\
\hline 2,4-diOH-BP / 4,4'-diOH-BP & 86.40 & 73.99 \\
\hline 2,2'-diOH-4-Me-BP & 81.92 & 79.18 \\
\hline
\end{tabular}

\section{LC-MS/MS method validation}

The optimized LC-MS/MS method performance parameters (selectivity/specificity, linearity, accuracy and precision, recovery, detection (LOD) and quantitation (LOQ) limits) were subjected to validation.

\section{Selectivity/specificity}

The method selectivity was assessed through the use SPE extraction procedure followed by LC-MS/MS analysis. The sample preparation procedure was applied in triplicate to a water sample that did not contain the target analytes. Following the repeat of the SPE extraction procedure, there was no interference in the selected transitions, demonstrating the selectivity of the method.

\section{Linearity}

The calibration curves were constructed by plotting the benzophenone derivatives peak area versus concentration in the range $1 \div 100 \mu \mathrm{g} / \mathrm{L}$. The linearity was confirmed, all correlation coefficients $\left(\mathrm{R}^{2}\right)$ being higher than 0.998 .

\section{Accuracy and precision}

For evaluation of the instrument repeatability, a blank sample spiked at two concentration levels (10 and $50 \mathrm{ng} / \mathrm{L})$ was analyzed by repeated injections (6 times) of the same sample subjected to the sample preparation procedure (solid phase extraction).

Accuracy and precision were determined by the analysis of both surface water and wastewater which not contained the target analytes, spiked at two concentration levels (10 and $50 \mathrm{ng} / \mathrm{L})$, with six replicates at each level. The relative standard deviation (RSD) calculated for repeatability (intra-day precision), was evaluated by repeating the procedure for the preparation and analysis of the samples on 6 sub-samples coming from the same sample for each matrix.

The intermediate precision (inter-day precision), expressed as RSD, was evaluated by applying the sample preparation procedure to a single sample of surface water and wastewater divided into 6 sub-samples, but were prepared on different days by two different analysts. The instrument repeatability was characterized by values of standard deviation (RSD\%) ranging from 1.03 to $1.25 \%$ for surface water and between 1.60 and $1.78 \%$ for wastewater. These values are well below the acceptability limit of instrument repeatability for an LC-MS method (5\% RSD).

Intra-day and inter-day precision were tested for two concentration levels (10 and $50 \mathrm{ng} / \mathrm{l})$ on 6 replicates for both types of matrix. For surface water matrix, method was precise with RSD\% values situated between 7.67 and $9.88 \%$ for lower concentration and 7.27 and $8.86 \%$ for higher concentration respectively (intra-day). For wastewater matrix, the 
relative standard deviation values determined for intra-day precision ranged between $10.06 \div 13.49 \%$ for 10 wer concentration and $9.4 \div 12.96 \%$ for higher concentration, respectively.

\section{Recovery}

Recoveries were determined by spiking treated water, ground water and river water, in triplicate, at a concentration of $50 \mathrm{ng} / \mathrm{L}$ of a mixture of benzophenone derivatives and extracted under the optimum conditions. The recovery values obtained by applying the extraction procedure ranged from $80 \div 95 \%$ for the surface water matrix and $79 \div 98 \%$ for the wastewater matrix. These values $(>70 \%)$ allow the quantitation of target analytes from both type water matrices from treatment plants by applying a correction factor inversely proportional to the yield reported.

\section{Limit of detection (LOD), limit of quantitation (LOQ)}

The detection (LOD) and quantitation (LOQ) limits were determined by injection of solutions with lower analyte concentrations until the experimentally determined signal to noise ratio was equal to 3 (LOD) and 10 (LOQ). For the determination of the global detection and quantitation limits of the method, which includes all the steps of sample preparation, the concentration factor used for the extraction of surface water samples (200 times) and wastewater (100 times) and the recovery of the analytes determined upon validation of the method. The values of the detection and quantitation limits thus determined are shown in Table 5.

Table 5

RECOVERY, DETECTION AND QUANTITATION LIMITS

\begin{tabular}{|c|c|c|c|c|c|c|}
\hline & \multicolumn{3}{|c|}{ Surface water } & \multicolumn{3}{c|}{ Wastewater } \\
\hline Analytes & $\begin{array}{c}\text { Recovery } \\
(\%)\end{array}$ & LOD (ng/L) & LOQ (ng/L) & $\begin{array}{c}\text { Recovery } \\
(\%)\end{array}$ & $\begin{array}{c}\text { LOD } \\
(\mathrm{ng} / \mathrm{L})\end{array}$ & $\begin{array}{c}\text { LOQ } \\
(\mathrm{ng} / \mathrm{L})\end{array}$ \\
\hline 2,2 ',4,4'-qOH-BP & 95 & 0.59 & 1.64 & 89 & 1.17 & 3.28 \\
\hline 2-OH-BP/4-OH-BP & 84 & 1.19 & 3.33 & 81 & 2.38 & 6.66 \\
\hline $\begin{array}{c}2,4-d i O H-B P / 4,4 '- \\
\text { diOH-BP }\end{array}$ & 84 & 1.11 & 3.11 & 82 & 2.22 & 6.22 \\
\hline 2,2'-diOH-4-Me-BP & 81 & 1.46 & 4.10 & 79 & 2.93 & 8.19 \\
\hline
\end{tabular}

Taking into account the sensitivity data obtained above, the developed LC-MS/MS method allows individual detection and confirmation of the six UV filters from surface water and wastewater samples at concentrations levels above 1.64 $\mathrm{ng} / \mathrm{L}$.

\section{Conclusions}

A sensitive analytical method based on SPE combined with LC-MS/MS for the determination of six benzophenone derivatives, used as organic UV-filter, in both surface water and wastewater is presented. Full validation of the method was carried out, giving statistically accurate results for fortified analyte-free samples.

Chromatographic conditions (including chromatographic column, mobile phase and modifier) and MS parameters were optimized to allow trace amounts detection of these contaminants in surface and wastewater samples. In all environmental samples, recovery efficiencies were ranged between 80 and $95 \%$ for surface water and between 79 and $98 \%$ for wastewater matrix. The method precision was evaluated on two concentration level (10 and $50 \mathrm{ng} / \mathrm{L}$ ) for both matrices. In case of surface water matrix, the RSD\% values were situated between 7.67 and $9.88 \%$ for lower concentration and 7.27 and $8.86 \%$ for higher concentration respectively (intra-day). The relative standard deviation values determined for wastewater matrix, intra-day precision ranged between $10.06 \div 13.49 \%$ for lower concentration and $9.4 \div$ $12.96 \%$ for higher concentration, respectively.

The overall LOQ for the six benzophenone derivatives were situated below $4.1 \mathrm{ng} / \mathrm{L}$ for surface water and below 8.19 $\mathrm{ng} / \mathrm{L}$ for wastewater matrices.

The described analytical method can be applied to benzophenone derivatives detection in real environmental water sample.

Acknowledgements: The authors acknowledge the financial support offered by The National Research Program "Nucleu" through contract no 20N/2019, Project code PN 19040101.

\section{References}

1.***Regulation (EC) No 1223/2009 of the European Parliament and of the Council of 30 November 2009 on Cosmetic Products. 2.AMINE, H., GOMEZ, E., HALWANI, J., CASELLAS, C., FENET, H., Mar. Pollut. Bull., 64, 2012, p 2434. 
3.SANTOS, A.J.M., MIRANDA, M.S., ESTEVES DA SILVA, J.C.G. Water. Res., 46, 2012, p 3167.

4.LANGFORD, K.H., THOMAS, K.V., J. Environ. Monit., 10, 2008, p 894.

5.FENT, K., ZENKER, A., RAPP, M., Environ. Pollut., 158, 2010, p 1817.

6.KUNISUE, T., WU, Q., TANABE, S., ALDOUS, K. M., KANNAN, K. Anal. Methods, 2, 2010, p 707.

7.ZHANG, Z., REN, N., LI, Y.F., KUNISUE, T., GAO, D., KANNAN, K., Environ. Sci. Technol., 45, 2011, p 3909.

8.FENT, K., KUNZ, P.Y., GOMEZ, E., Chimia, 62, 2008, p 368.

9.SCHLUMPF, M., COTTON, B., CONSCIENCE, M., HALLER, V., STEINMANN, B., LICHTENSTEIGER, W., Environ. Health Perspect., 109, 2001, p 239.

10.Environmental Working Group. EWG's Skin Deep Cosmetic Database. http://www.ewg.org/skindeep/:available on December, 2011.

11.HAYDEN, C.G.J., ROBERTS, M.S., BENSON, H.A.E. Lancet, 350, 1997, p 863.

212.JANJUA, N.R., MOGENSEN, B., ANDERSSON, A.M., PETERSEN, J.H., HENRIKSEN, M., SKAKKEBÆK, N. E., J. Invest. Dematol., 123, 2004, p 57.

13.NAKAGAWA, Y., SUZUKI, T., Chem-Biol. Interact., 139, 2002, p 115.

214..MOROHOSHI, K., YAMAMOTO, H., KAMATA, R., SHIRAISHI, F., KODA, T., MORITA, M., Toxicol. in Vitro, 19,2005, p 457.

15.LI, M., SUN, Q., LI, Y., LV, M., LIN, L., WU, Y., ASHFAQ, M., YU, C.P., Anal Bioanal Chem., 408, no 18, 2016 , p 4953.

16.PETRE, J., GALAON, T., IANCU, V.I., VASILE, G.G., STANESCU, E., PASCU, L.F., SIMION, M., CRUCERU, L., Rev. Chim. (Bucharest), 67, no 8, 2016, p 1436.

17.GAlAON, T., PETRE, J., IANCU, V.I., CRUCERU, L., VASILE, G., PASCU, L.F., LEHR, C.B., Rev. Chim. (Bucharest), 67, no 8, 2016, p 1474.

18.CHIRIAC, F.L., PAUN, I., PIRVU, F., CRUCERU, L., PASCU, L.F., GALAON, T., Rev. Chim. (Bucharest), 69, no 11, 2018 , p 4129.

19.GALAON, T., CRUCERU, L., PETRE, J., PASCU, L.F., IANCU, V.I., NICULESCU, M., J. Environ. Prot. Ecol., 17, no 1, 2016 , p 74.

20.CHIRIAC, F.L., CRUCERU, L., NICULESCU, M., PASCU, L.F., LEHR, C.B., GALAON, T., Rev. Chim. (Bucharest), 68, no 8, 2017 , p 1685.

$\overline{\text { Manuscript receivedL 31.07.2019 }}$ 